\title{
Physical Assessment of Barangka Tugurara Towards Volcanic Hazards of Gamalama Volcano
}

\author{
Estuning Tyas Wulan Mei, \\ Faculty of Geography, Universitas Gadjah Mada \\ Yogyakarta, Indonesia \\ Corresponding email: estu.mei@geo.ugm.ac.id \\ Djati Mardianto, \\ Faculty of Geography, Universitas Gadjah Mada \\ Yogyakarta, Indonesia \\ Evita Pamudianti, \\ Faculty of Geography, Universitas Gadjah Mada \\ Yogyakarta, Indonesia \\ Dwi Yanti Amalia, \\ Faculty of Geography, Universitas Gadjah Mada \\ Yogyakarta, Indonesia
}

\begin{abstract}
Gamalama volcano is an active volcano located in Ternate Island. Besides volcanic ash and lava, lahars is one of the volcanic hazards threatening the Island. One of the rivers being susceptible to lahars flood is Barangka (River) Tugurara. The downstream of this river is very densely populated creating high risk to the community. According to this issue, therefore it is important to conduct physical assessment of the Barangka. The research uses field survey and Analytic Hierarchy Process (AHP) methods. The data used for this research including geomorphological and topographical data, river width, rainfall intensity, slope, and land use. The result shows that volcanic hazards of the Barangka may be classified into high and medium levels. The high level of volcanic hazards is located in the break of slope caused by a meeting point between the two flows of volcanic material. The medium level of volcanic hazards is located in the downstream area caused by sedimentation of volcanic material.
\end{abstract}

Keywords-Barangka tugurara, gamalama, ternate island, volcanic hazards

\section{INTRODUCTION}

Gamalama Volcano is one example of volcanoes located in a small island, the island of Ternate. According to the data from the Indonesian Ministry of Energy and Mineral Resources, Gamalama volcano has a history of eruptions from 1538 until 2014. There are two types of volcanic hazards in Gamalama Volcano, i.e. the primary hazards including pyroclastic eruptions, lava flows and volcanic ash while the secondary hazards such as sediment flows (lahars flow). According (Bacharudin et al. 1996), the Gamalama volcanic eruption is generally followed by volcanic bombs, lapilli, and other loose materials and sometimes followed by lava flows.
Gamalama volcano is an island formed by volcanic formation process that emerged from the sea floor. According to Firmansyah (2011), the island of Ternate is part of the body of the volcano (Gamalama volcanic foot slope and Gamalama volcanic body-summit). Gamalama volcano foot slope is a volcano area with a slope of ramps, located in the east, north, and south of the Gamalama volcano and extended to the beach.

Types of rock that composed the morphology of the foot slope is volcanic tuff rock. According to the Gamalama volcano stratigraphy, the island of Ternate is composed by Holocene volcanic materials which consist of volcanic breccia, andesite lava, sand, and tuffs.

The study area of this research is Barangka Tugurara. It is located within the watershed Tugurara that included into seven administrative unit (villages), namely Akehuda, Dufa-Dufa, Tubo, Moya, Tafure and Toloko. Barangka means seasonal river having no water flow (except during rainy days). Based on the map of Volcanic Disaster Prone Region of Gamalama Volcano in Figure 1, the Barangka Tugurara has the highest volcanic hazard since the volcano provides many materials supplies from eruptions (Bacharudin et al., 1996). In 2012, there was lahars flows occurred in the Barangka and caused infrastructure damages and death toll. Due to the high potential hazards in the Barangka Tugurara, this study aims to assess the physical condition of Tugurara Gamalama and identify the primary and secondary hazards of the volcano. 


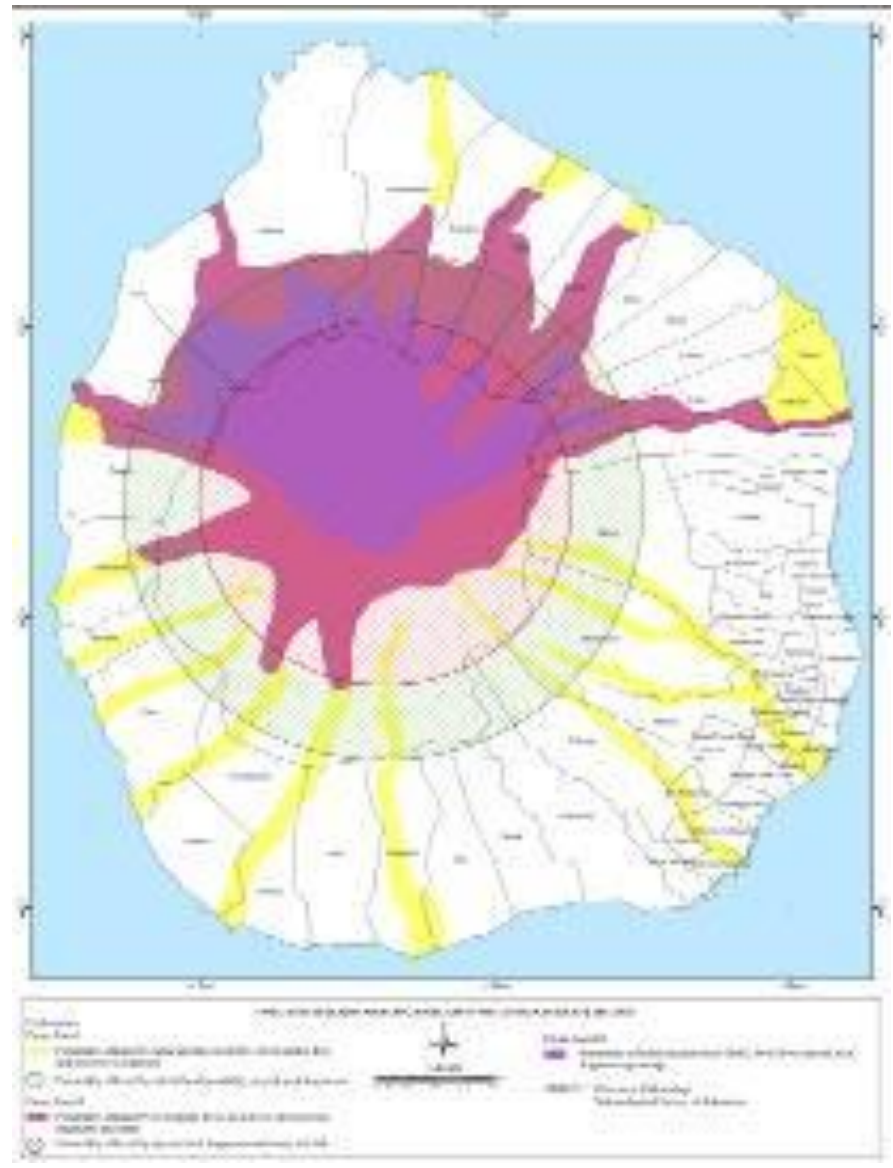

Fig 1. Volcanic Hazard Map of Gamalama Volcano (Bacharudin et al. 1996)

\section{METHOD}

\section{A. Assessment Physical Condition of the Barangka Tugurara}

The assessment of Barangka Tugurara physical conditions is conducted by a series of activities including Gamalama volcanic hazards maps analysis, direct observations in the field, and assessment using analytical hierarchy process (AHP). Primary and secondary data were used in this study. Primary data were obtained from measurements and observations on field, while secondary data obtained from maps or documents from relevant agencies, as well as previous research. Primary data used in the study including Barangka Tugurara morphological data, observation on lava outcrops and present land use. While secondary data including historical data on eruption activities of Gamalama Volcano, land use, rivers, etc.

Field sampling including identification of lahars outcrop and river morphological measurement. The samples of river morphology and lahars outcrops were selected by using purposive sampling method. Each sample was based on the morphological changes of the Barangka Tugurara. Figure 2 shows nine sample points were examined during the fieldwork. The sample point was based on the change of the characteristic of river meander.

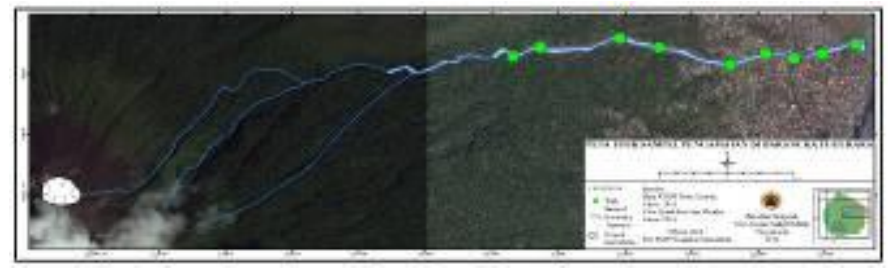

Fig 2. Sample points map

\section{B. Analytical Hierarchy Process (AHP)}

In this paper, we tried to mapping the Gamalama volcanic hazards using Analytical Hierarchy Process (AHP). AHP is a mapping method for solving complex problems through tiered system (hierarchy) to determine priority and value of the index weighting (Wacano, 2014). The AHP method uses parameters and variables as the value of consistency (consistency ratio/CR), therefore the results will be closer to the actual condition. The CR value based on a comparison matrix in AHP cannot exceed the value of 0.1 . It is used to meet the requirements of consistency weighting (Wacano, 2014).

In this study, we mapped the Gamalama volcanic hazard with a focus on lahars hazard in Barangka Tugurara. Lahars can be categorized as debris flow included in the mass movement (mass wasting), therefore in this study we use the AHP method based on LSI (Landslide Susceptibility Index). LSI calculates the level of landslide susceptibility based on a combination of linear weighting of the causative factors and classification of landslide susceptibility (Thanh \& De Smedt, 2012). LSI formula used in this paper is as follow:

$$
\text { LSI }=\sum_{j=1}^{n} W_{j} \text { wij }
$$

Where,

LSI : susceptibility index;

$\mathrm{W}_{j} \quad$ : weight of each parameter

$\mathrm{w}_{i j} \quad$ : weight of class $(i)$ in parameter $(j)$

$N \quad$ : parameter number

The weight of $\mathrm{W}_{j}$ and $\mathrm{w}_{i j}$ is quantitively determined by the pair - comparisons (pairwise) and the calculation of the weights. $\mathrm{Wj}$ value is obtained as the main weight value on a matrix that describes the cause of the preferences between different factors. Wij value as the value of the vector of the matrix that describes the preferences with class parameters. This matrix is obtained by applying a scale of mate preference - ratio (pairwise) each parameter as in Table 1. 
TABLE I. PREFERENCE INDEX BETWEEN TWO PARAMETERS IN AHP

\begin{tabular}{|c|c|l|}
\hline Scale & Preference Index & \multicolumn{1}{|c|}{ Additional information } \\
\hline 1 & Same & $\begin{array}{l}\text { Two parameters have the equal effect on } \\
\text { landslide susceptibility }\end{array}$ \\
\hline 3 & Moderate & $\begin{array}{l}\text { One parameter has similarities to other } \\
\text { parameter in the landslide susceptibility }\end{array}$ \\
\hline 5 & High & $\begin{array}{l}\text { One parameter supports the landslide } \\
\text { susceptibility assessment to other } \\
\text { parameter }\end{array}$ \\
\hline 7 & Very High & $\begin{array}{l}\text { One parameter has major influence on } \\
\text { other parameter }\end{array}$ \\
\hline 9 & Supreme & $\begin{array}{l}\text { Strong evidence in the field related to } \\
\text { landslide }\end{array}$ \\
\hline $2,4,6,8$ & Secondary & $\begin{array}{l}\text { Used to represent the preferences in } \\
\text { weighting scale of } 1,3,5,7, \text { and } 9\end{array}$ \\
\hline Reverse & Contrast & Used for reverse comparison \\
\hline
\end{tabular}

Source : (Saaty, 2000)

An important aspect of AHP is the ability to evaluate the consistency of preference ratings. Consistency index (CI) is an index as a measure of consistency. CI formula used is as follow:

$$
\mathrm{CI}=\frac{\Omega \max -n}{n-1}
$$

where, $\chi_{\max }$ is the largest weight value of the preference matrix and $\mathrm{n}$ is a value (number of parameters) consistency index compared with random consistency index (Table 2). The formula to calculate the consistency ratio as follow:

$$
\mathrm{CR}=\frac{G I}{R I} \times 100 \%
$$

If the value of consistency ratio is greater than $10 \%$, then the subjective assessment in pair-wise comparison between parameter is not consistent and needs to be fixed.

\section{TABLE II. CONSISTENCY RANDOM INDEX (RI)}

\begin{tabular}{|c|c|c|c|c|c|c|c|c|c|}
\hline $\mathbf{1}$ & $\mathbf{2}$ & $\mathbf{3}$ & $\mathbf{4}$ & $\mathbf{5}$ & $\mathbf{6}$ & $\mathbf{7}$ & $\mathbf{8}$ & $\mathbf{9}$ & $\mathbf{1 0}$ \\
\hline $\mathbf{0}$ & 0 & 0,58 & 0,9 & 1,12 & 1,24 & 1,32 & 1,41 & 1,45 & 1,49 \\
\hline
\end{tabular}

According to Wacano (2014), the eigenvector used as a basis for analysis. In this study, the eigenvector is used to map the volcanic hazard in Gamalama Volcano. AHP analysis is done by using a semi-statistical analysis with weighted values obtained through the comparison matrix and control the value of the index ratio which is less than 0,1 .

\section{FINDING AND DISCUSSION}

\section{A. Hazard Zone Map (Kawasan Rawan Bencana/KRB)}

There are three hazard zones in Barangka Tugurara, namely KRB III, KRB II and KRB I (Figure 3). KRB III is an area that is often devastated by lava flows and incandescent rock avalanches. KRB III is located in the villages of Dufa-Dufa and Tubo. KRB II is an area that could potentially devastated by lava flows, burst/ incandescent rock avalanches. KRB II is located in the villages of Tubo, Dufa-Dufa, Moya, Akehuda, and Tafure. KRB I is an area that could potentially devastated by lahars flows and lava flows likely to be exposed. KRB I is located in the villages of Tubo, Dufa-Dufa, Akehuda, and Tafure.

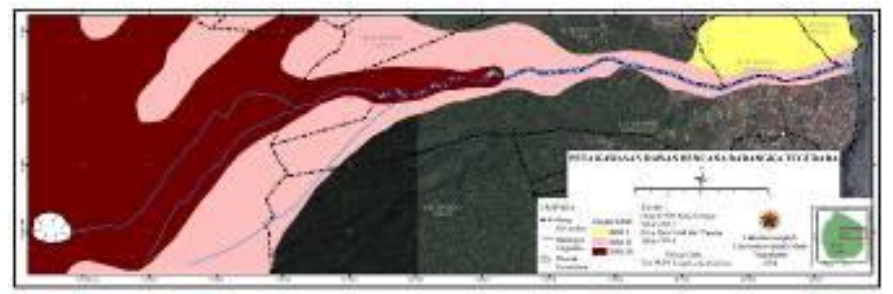

Fig 3. Hazard zone map of Barangka Tugurara

There are two types of volcanic hazards of Gamalama, namely primary and secondary danger hazard. The primary hazards consists of lava flows, pyroclastic flows, volcanic bombs and ash, while the secondary hazards occur indirectly or after an eruption i.e. lahars flow. Due to the very short distance of the river (from the summit to the sea) causing the area around Barangka Tugurara becomes very prone to volcanic eruptions.

\section{B. Physical Condition of Barangka Tugurara}

The physical condition Barangka Tugurara is generally affected by different kind of human activities such as dredging material, infrastructures, i.e. jetties, dikes, and Sabo-dam. We took nine sample points in the field, each point is chosen based on morphological changes of Barangka Tugurara either in settlement or in non-settlement areas.

According to the figure 4, there are four sample points located in the non-settlement areas. The first (coordinate: 318161-0090645) and second (318364-0090716) points showed that the river is still in their natural condition (no dyke). The rock/material condition of the first and second sample points are dominated by rocky material with gravel to sand size. The shape of the valley on both sample is "deep U" shape. This form is due to the absence of the water flow which erode the base of the river, while the distance of the points to the volcano summit is approximately 2.9-3.0 kilometers. In the first sample points we found the formation of a lava flow that indicates the boundary between KRB III and II.

The third, fourth and fifth sample points have the similar physical conditions. The rock materials at the three sample points are mostly lump to sand size. The shape of the river in these three locations are $U$ shape but wider than in the stream. Most probably, this shape is due to the lahars flows occurred in 2011 and 2012. The water flow carried material from lump to clay size and then accumulate in the bottom of the river as shown in the figure 5 .

As shown in the figure 6, there are five sample points in the settlement area. The sixth and seventh sample points have the shape "deep U". There is no change of valley morphology in the sixth and seventh sample points, compared to the previous sample points $\left(3^{\text {rd }}, 4^{\text {th }}\right.$ and $\left.5^{\text {th }}\right)$. This is due to levee construction before the 2011 and 2012 lahars flows. However, 
due to the small storage capacity of the river, the overflows of lahars went to the left and right areas of Barangka Tugurara. The material of the lahars that can be identified during the fieldwork were sands, gravels and boulders.

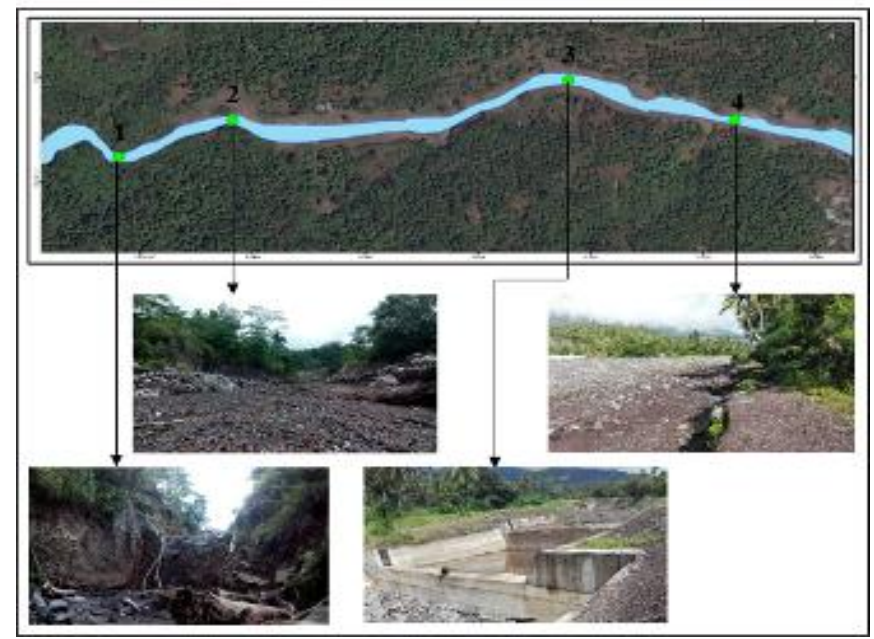

Fig 4. Field observation in non-built-up areas
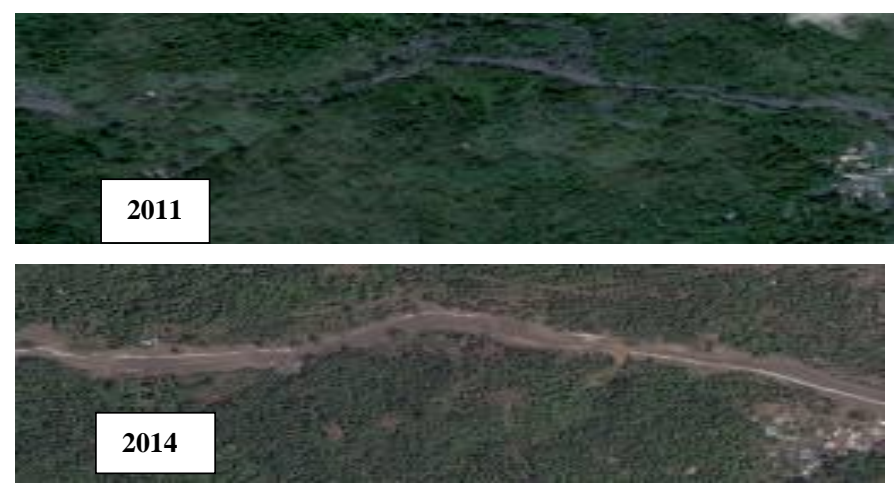

Fig 5. River morphological changes from 2011-2014

The eighth and ninth sample points are lies at the estuary of Barangka Tugurara. In this level, the shape of the river is wide $\mathrm{U}$ shape. The ninth sample point is affected by the marine tides. As shown in the figure 7, we still find big size materials. It shows the difference between the nature of lahars and water when transporting materials. Lahars may transport very big and heavy material. According to this condition, the estuary of the river is not suitable for settlement.

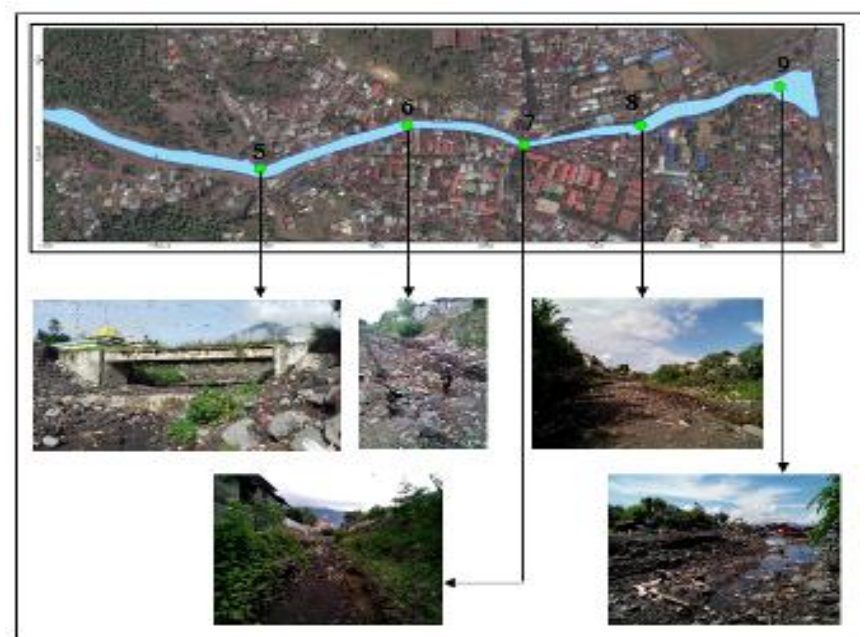

Fig. 6. Field observation in settlements areas
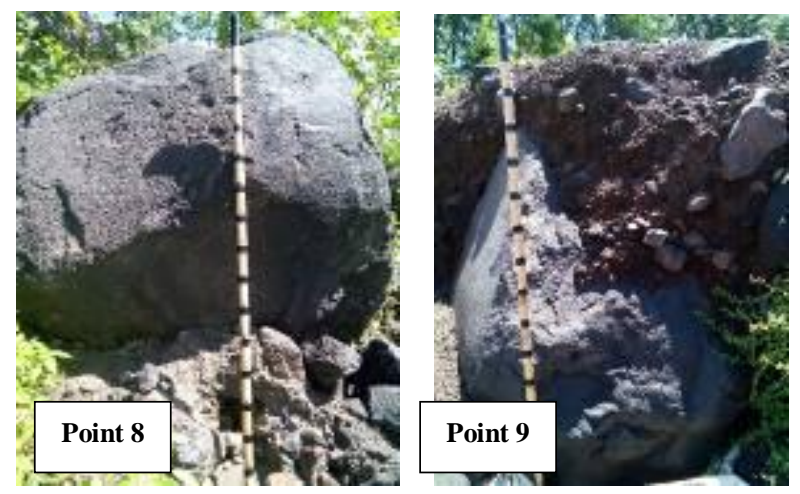

Fig 7. Blocks of samples in points 8 and 9

\section{Analytical Hierarchical Process (AHP)}

Susceptibility mapping of Gamalama volcanic hazards in Barangka Tugurara consists of five aspects, namely geomorphology, slope, topography, distance from the river, and land use. Based on the calculation, assessment aspects that affected the value of AHP is determined by the consistency ratio $(\mathrm{CR})$. CR is used must not be more than $10 \%$. This is because of subjective judgment in the comparison between the parameter pair is inconsistent and needs to be repaired. Based on calculations from the Table III CR, both of each parameter proves that values below $10 \%$, it means that the calculation results can be considered consistent.

In this study, geomorphology aspect is defined as the study of landforms. We used five main aspects including morphology, morpho-structure, morpho-genesis, morphochronology and morpho-arransement. According to (Thornbury, 1969) landform is the configuration of the earth's surface with typical relief, controlled by the geological process for a certain material and a certain scale of time and space. 
TABLE III. AHP VALUE OF LANDFORMS

\begin{tabular}{|l|r|}
\hline \multicolumn{1}{|c|}{ Aspect } & CR (\%) \\
\hline Slope & 0.184583 \\
\hline Topography & 0.0121861 \\
\hline River & 0.1176624 \\
\hline Land use & 0.0313006 \\
\hline Landform & 0.1578113 \\
\hline
\end{tabular}

As shown in table IV AHP value of Landforms consists of a volcanic cone, volcanic slopes, downslope volcanic and volcanic feet. The volcanic cone is the main pathway for the lava flow. While the lahars may occur when the sediments are mixed with water from the rain. The upper slopes of the volcanic landforms map of Barangka Tugurara is dominating the entire landform. The middle volcanic slopes is a place of transition from upper volcanic slopes to lower volcanic slopes. This area is where the volcanic material is deposited. In addition, due to high rainfall in this area, lahar hazard becomes one of the deadliest direct hazards to the people living near to the river.

TABLE IV. AHP VALUE OF LANDFORMS

\begin{tabular}{|c|c|c|c|c|c|c|c|c|}
\hline \multirow{2}{*}{ Landform } & \multicolumn{6}{|c|}{ Matriks comparison pair-wise } & \multirow{2}{*}{$\begin{array}{l}\text { Eigen } \\
\text { vector }\end{array}$} & \multirow{2}{*}{$\begin{array}{c}\text { LSI } \\
\text { Faktor }\end{array}$} \\
\hline & 1 & 2 & 3 & 4 & 5 & 6 & & \\
\hline $\begin{array}{l}\text { Kerucut } \\
\text { Vulkanik }\end{array}$ & 1.0 & 6.0 & 5.0 & 4.0 & 3.0 & 2.0 & 0.435 & 0.228 \\
\hline $\begin{array}{l}\text { Lereng } \\
\text { Vulkanik } \\
\text { Atas }\end{array}$ & 0.5 & 1.0 & 5.0 & 4.0 & 3.0 & 2.0 & 0.247 & 0.130 \\
\hline $\begin{array}{l}\text { Lereng } \\
\text { Vulkanik } \\
\text { Tengah }\end{array}$ & 0.3 & 0.5 & 1.0 & 2.0 & 2.0 & 0.5 & 0.111 & 0.058 \\
\hline $\begin{array}{l}\text { Lereng } \\
\text { Vulkanik } \\
\text { Bawah }\end{array}$ & 0.3 & 0.3 & 0.3 & 1.0 & 4.0 & 3.0 & 0.112 & 0.059 \\
\hline $\begin{array}{l}\text { Kaki } \\
\text { Vulkanik }\end{array}$ & 0.2 & 0.3 & 0.3 & 0.3 & 1.0 & 4.0 & 0.060 & 0.031 \\
\hline $\begin{array}{l}\text { Dataran } \\
\text { Kaki } \\
\text { Vulkanik }\end{array}$ & 0.2 & 0.2 & 0.3 & 0.3 & 0.5 & 1.0 & 0.035 & 0.019 \\
\hline
\end{tabular}

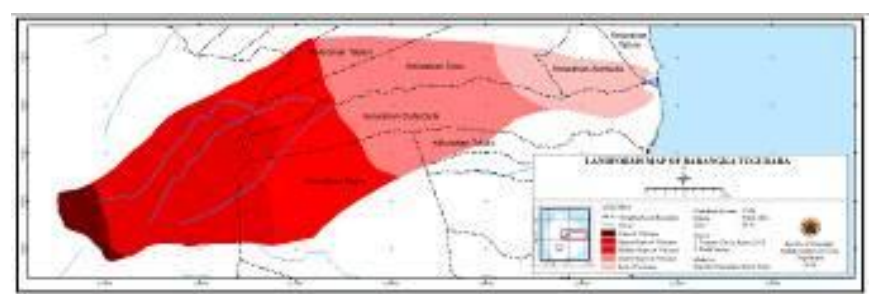

Fig 8. Landform Map of Barangka Tugurara

The second aspect in table V AHP value is the slope. This aspect is the most influencing factor, since it is directly affected by the force of gravity and topographic aspects. The greater the slope, it may create very strong gravity force. The higher the place, the rain more likely occurs in the area. In this study we divide four classes of slope: more than $65^{\circ} ; 65^{\circ}-31^{\circ}$; $30^{\circ}-8^{\circ}$; and, less than $8^{\circ}$.
TABLE V. AHP VALUE OF SLOPE

\begin{tabular}{|l|c|c|c|c|c|r|r|r|}
\hline \multirow{2}{*}{ Slope } & \multicolumn{6}{|c|}{ Matriks komparasi pair-wise } & \multirow{2}{*}{ Eigenvektor } & $\begin{array}{c}\text { LSI } \\
\text { Faktor }\end{array}$ \\
\cline { 2 - 8 } & $\mathbf{1}$ & $\mathbf{2}$ & $\mathbf{3}$ & $\mathbf{4}$ & $\mathbf{5}$ & $\mathbf{6}$ & & 0.491 \\
\hline$<8$ & 1.0 & 4.0 & 3.0 & 2.0 & & & 0.020 \\
\hline $8-30$ & 0.5 & 1.0 & 3.0 & 3.0 & & & 0.278 & 0.011 \\
\hline $31-65$ & 0.3 & 0.5 & 1.0 & 3.0 & & & 0.152 & 0.006 \\
\hline$>65$ & 0.3 & 0.3 & 0.5 & 1.0 & & & 0.079 & 0.003 \\
\hline
\end{tabular}

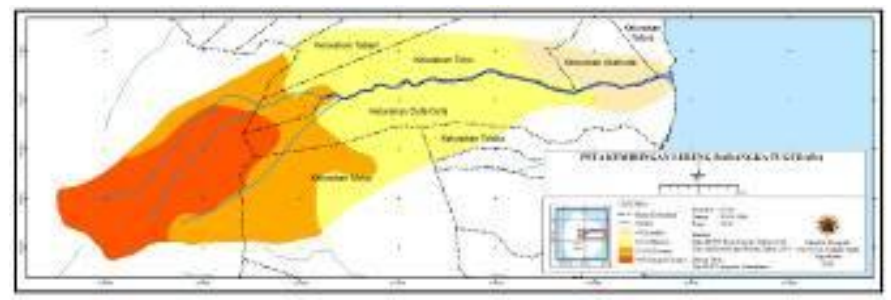

Fig 9. Slope Map of Barangka Tugurara

The third aspect in table VI AHP value is the topography. The topography and slope are interrelated and influencing each other. As shown in figure 10, the Barangka Tugurara is divided into 4 classes of altitude: more than $1200 \mathrm{~m}$ above sea level; 1200-801 masl, 800-401 masl and less than 400 masl. The material from lahars flow will be easily transported in the steep slope, while the sediments will be easily deposit in the low land areas.

TABLE VI. AHP VALUE OF TOPOGRAPHY

\begin{tabular}{|l|c|c|c|c|c|c|c|c|}
\hline \multirow{2}{*}{ Topography } & \multicolumn{6}{|c|}{ Matriks comparison pair- } & \multirow{2}{*}{ Eigenvector } & \multirow{2}{*}{$\begin{array}{c}\text { LSI } \\
\text { Faktor }\end{array}$} \\
\cline { 2 - 7 } & $\mathbf{1}$ & $\mathbf{2}$ & $\mathbf{3}$ & $\mathbf{4}$ & $\mathbf{5}$ & $\mathbf{6}$ & & \\
\hline$<400$ & 1.0 & 0.3 & 0.3 & 0.5 & & & 0.115 & 0.028 \\
\hline $401-800$ & 2.0 & 1.0 & 0.3 & 0.3 & & & 0.145 & 0.035 \\
\hline $801-1200$ & 3.0 & 2.0 & 1.0 & 0.3 & & & 0.264 & 0.063 \\
\hline$>1200$ & 4.0 & 3.0 & 2.0 & 1.0 & & & 0.477 & 0.115 \\
\hline
\end{tabular}

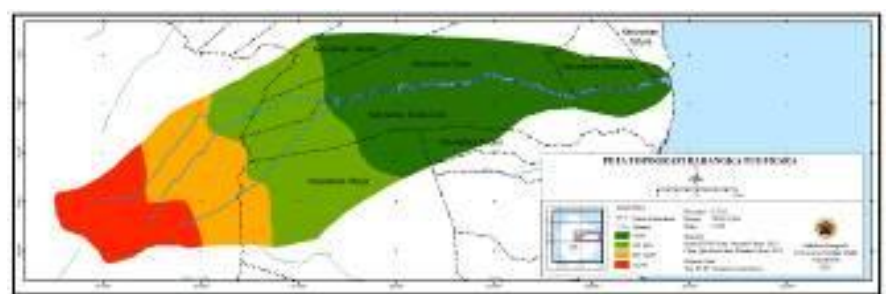

Fig 10. Topographical Map of Barangka Tugurara

The fourth aspect table VII AHP value is the distance from the river. This aspect is particularly important for the analysis of overflowing river. In this study, we create the scenario of the river buffer, respectively 25 meters and 50 meters (figure 11).

TABLE VII. AHP VALUE OF RIVER

\begin{tabular}{|l|c|c|c|c|c|c|r|r|}
\hline \multirow{2}{*}{ River } & \multicolumn{6}{|c|}{ Matriks comparison pair- } & \multirow{2}{*}{ Eigenvector } & $\begin{array}{c}\text { LSI } \\
\text { Faktor }\end{array}$ \\
\cline { 2 - 6 } & $\mathbf{1}$ & $\mathbf{2}$ & $\mathbf{3}$ & $\mathbf{4}$ & $\mathbf{5}$ & $\mathbf{6}$ & & \\
\hline$<25$ & 1.0 & 3.0 & 2.0 & & & & 0.564 & 0.031 \\
\hline $25-50$ & 0.5 & 1.0 & 3.0 & & & & 0.309 & 0.017 \\
\hline$>50$ & 0.3 & 0.3 & 1.0 & & & & 0.128 & 0.007 \\
\hline
\end{tabular}




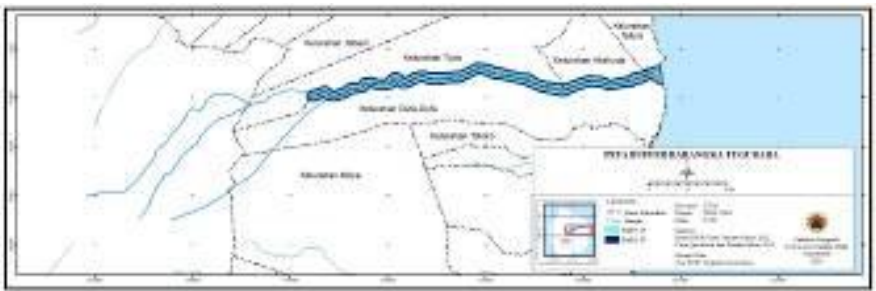

Fig 11. Topographical Map of Barangka Tugurara

The fifth aspect table VIII AHP value is the land use. This aspect is very important to identify not only hazard, but also risk from Gamalama volcanic eruption. Figure 12 shows the land use around Barangka Tugurara consists of shrubs, forests, gardens and settlements. The land use map show that the residential areas are mostly located in the volcanic footslope. In case of lahars flow, this area might be affected by the lahars.

TABLE VIII. AHP VALUE OF LANDUSE

\begin{tabular}{|c|c|c|c|c|c|c|c|c|}
\hline \multirow{2}{*}{ Landuse } & \multicolumn{6}{|c|}{$\begin{array}{c}\text { Matriks comparison pair- } \\
\text { wise } \\
\end{array}$} & \multirow{2}{*}{ Eigenvektor } & \multirow{2}{*}{\begin{tabular}{|c} 
LSI \\
Fakt \\
or
\end{tabular}} \\
\hline & 1 & 2 & 3 & 4 & 5 & 6 & & \\
\hline Pemukiman & 1.0 & 2.0 & 0.5 & 0.3 & & & 0.280 & 0.010 \\
\hline Kebun & 2.0 & 1.0 & 2.0 & 0.3 & & & 0.356 & 0.013 \\
\hline Hutan & 2.0 & 0.5 & 1.0 & 0.5 & & & 0.252 & 0.009 \\
\hline Belukar/Semak & 0.5 & 0.3 & 0.3 & 1.0 & & & 0.112 & 0.004 \\
\hline
\end{tabular}

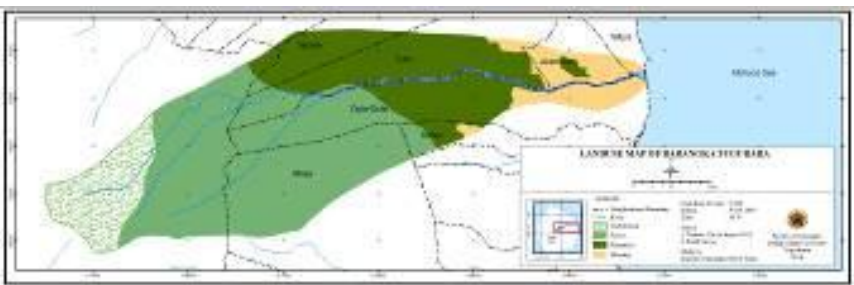

Fig 12. Land Use Map of Barangka Tugurara

This study tried to map the volcanic susceptibility by using five aspects as mentioned earlier (geomorphology, slope, topography, distance from the river, and land use) in analytical hierarchical process in order to classify the area into three main classes: high, medium and low hazard susceptibility (figure 13).

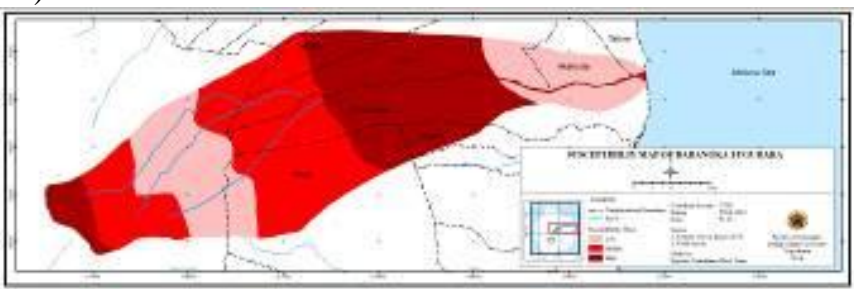

Fig 13. Hazard Zone Map of Barangka Tugurara

The areas having high susceptibility classes are in the upper and middle stream of the Barangka Tugurara with total area affected is $34 \%$. The high susceptibility class area in the upper stream is associated with conical landforms which is the center of volcanic activity Gamalama. While the high susceptibility in the middle stream of Barangka Tugurara is influenced by meeting points of small rivers and the accumulation of material flow.

The region having moderate susceptibility class is located in the upstream of Barangka Tugurara (38\%). In this area, topographic aspect is dominant. The region having low vulnerability class is located in the downstream of Barangka Tugurara $(28 \%)$. The low susceptibility is due to the decrease of the dominant aspects that influence susceptibility, i.e. topography and slope.

\section{CONCLUSION AND SUGGESTIONS}

Barangka Tugurara is one of the rivers passed by lahars in Ternate Island. There are at least six villages located along the river, namely Dufa-Dufa, Tubo, Tafure, Moya, Toloko, and Tabam. The villages which are located in the most prone area of Gamalama volcanic hazard are Akehuda, Dufa-Dufa, and Tubo. Some volcano hazards along the Barangka Tugurara comprises pyroclastic flows, lava flows, lahars flows and volcanic ash.

The volcanic susceptibility mapping of Barangka Tugurara is based on five aspects which are geomorphology, slope, topography, distance of the river, and land use. The results show that there are three classes of volcanic susceptibility map, which are high (34\% of the area), medium (38\% of the area) and low (28\% of the area). The highest level of volcanic prone area is situated at the break of slope since it is the meeting point of two flows. The moderate one is located in the downstream due to sedimentation of volcanic materials.

\section{REFERENCES}

[1] Bacharudin, R., Martono, A, \& Djuhara, A, 1996, "Peta Kawasan Rawan Bencana Gunungapi Gamalama, Ternate, Maluku," Bandung: Direktorat Vulkanologi.

[2] Firmansyah, 2011, "Identifikasi tingkat risiko bencana letusan Gunung Api Gamalama di Kota Ternate," Jurnal Lingkungan dan Bencana Geologi, 2(3), pp.203 - 219.

[3] Saaty, T., 2000, "Fundamentals of Decision Making and Priority Theory With the Analytic Hierarchy Process," RWS Publications.

[4] Thanh, L.N, \& De Smedt, F., 2012, "Application of an analytical hierarchical process approach for landslide susceptibility mapping in A Luoi district, Thua Thien Hue Province," Vietnam, Environmental Earth Sciences, 66(7), pp.1739-1752. Available at: http://dx.doi.org/10.1007/s12665-011-1397-x.

[5] Thornbury, W.D., 1969, "Principles of Geomorphology," John Wiley \& Sons Inc.

[6] Wacano, D., 2014, "Studi Kelayakan Potensi Mineral Tambang PasirBatu Menggunakan Pendekatan Litofasies dan Proses Geomorfik pada Alur Sungai Gendol Pasca Erupsi Gunungapi Merapi 2010," Jakarta: Universitas Gadjah Mada. 